\author{
Athier Hussin \\ Samawah, Iraq \\ samawea1234@yahoo.com
}

\section{Comparison of the Trends of Mean Temperature and Rainfall Rate in the City of Samawah (Iraq) with Global Climate Change}

Received on: 05/10/2018

Accepted on: 10/01/2019

Published online: 25/04/2019
Abstract-Increasing earth temperature due to the high level of greenhouse gas has affected the other climate elements on the earth surface. However, there was a little consideration of the differences between the global and local scale of climate change. This research included a comparison between the global climate change and the changes of climate elements that happened in Samawah city. The results showed that there is a significant difference between the increasing annual mean temperature globally and the annual mean temperature in the city. For example, when comparing the increase in annual mean temperature of the city for the period from 2006 to 2015 (ten years) with annual mean temperature globally based on the average of mean temperature for the previous 30 years (1975-2005), we note that there was increasing for the years 2010 and 2011 is almost four times and it was double for the years 2012, 2013, 2014 and 2015 higher than the increasing of annual mean temperature for the same years globally. Also, the mean temperature of the hot months of the summer season (JJA) in the city increased significantly compared to the rest of the months of the year and it is quite different from the change that occurred in the monthly mean temperature globally. Moreover, the annual average of precipitation in the city has fluctuated significantly due to the changes in climate and contrast to the increase in its global average. All these changes in the climate of the city will inevitably have an impact on the environment such as increasing drought, desertification and dust storms.

Keywords: climate change, mean temperature, global, Iraq

How to cite this article: A. Hussin, "Comparison the Trends of Mean Temperature and Rainfall Rate in the City of Samawah (Iraq) with Global Climate Change," Engineering and Technology Journal, Vol. 37, Part C, No. 1, pp. 168-174, 2019.

\section{Introduction}

During the previous 200 years, the earth has been experienced an increase in the concentration of atmospheric carbon dioxide $\left(\mathrm{CO}_{2}\right)$ by about 120 ppm as a result of using fusil fuels that result in preventing infrared radiation from being crossing toward free space [1]. Despite the accelerated increase in the concentration of carbon dioxide in the earth's atmosphere from 1970 to 2010 the significant increase in the $\mathrm{CO}_{2}$ concentration, as well as the other greenhouse gases (Figure 1), occurred from 2000 to 2010 [2]. High level of greenhouse gas in the atmosphere has caused increasing earth temperature (Figure 2). The term global warming created first time by Broecker when he used a simple model to predict the change in global temperature in conjunction with the increasing concentration of $\mathrm{CO}_{2}$ in the Earth's atmosphere [3]. However, several natural drivers can also affect global temperature such as sun activity. Therefore, global temperature will also naturally different from time to time. The investigation of natural climate change in different timescales requires long term and highresolution data [4].
Along with of $20^{\text {th }}$ century, earth temperature increased by about $0.7^{\circ} \mathrm{C}[5]$. There is evidence that the temperatures of Northern Hemisphere and South Hemisphere have been risen by $1.12^{\circ} \mathrm{C}$ and $0.84^{\circ} \mathrm{C}$ respectively during the period 1901 2010 [6]. Although large areas of Northern Hemisphere experienced the greatest warming in term of absolute values, the warming in the mid to lower latitudes of the earth was most significant [4]. It is clear that the extent and magnitude of earth temperature increase in global scale varied on the earth surface and even a few areas have experienced cooling [4]. For example, the warming of the sea is lower than the warming of land surface during the period of 1970s [7]. There are many factors that can affect the surface air temperature. Therefore, the observations of local air temperature need to merge with the temperatures observations of large scale to determine the temperature rise accurately [8]. 


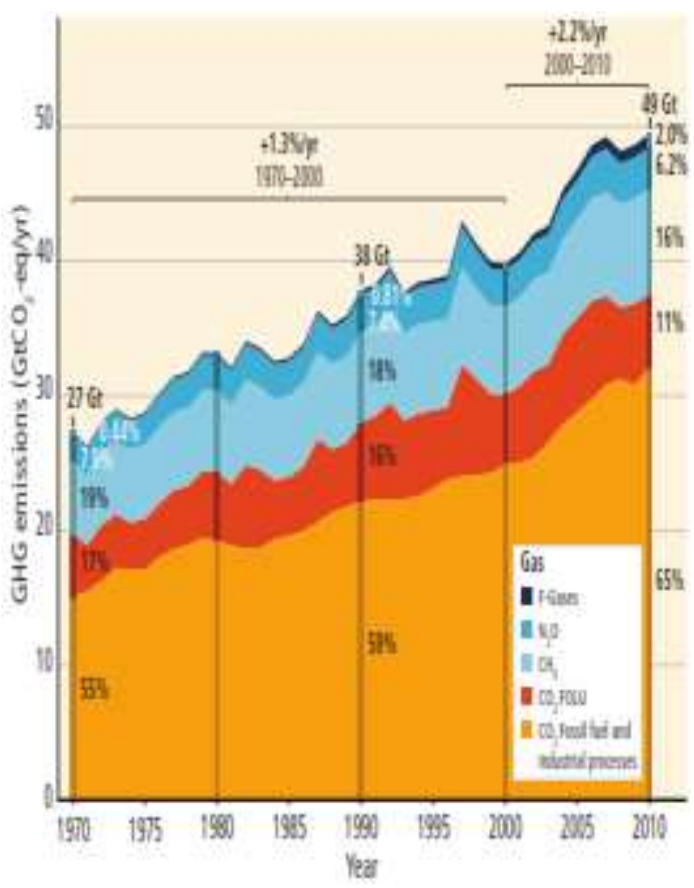

Figure 1: The change of GHGs concentration since 1970 (Source: IPCC, Climate Change: Synthesis Report, 2014)

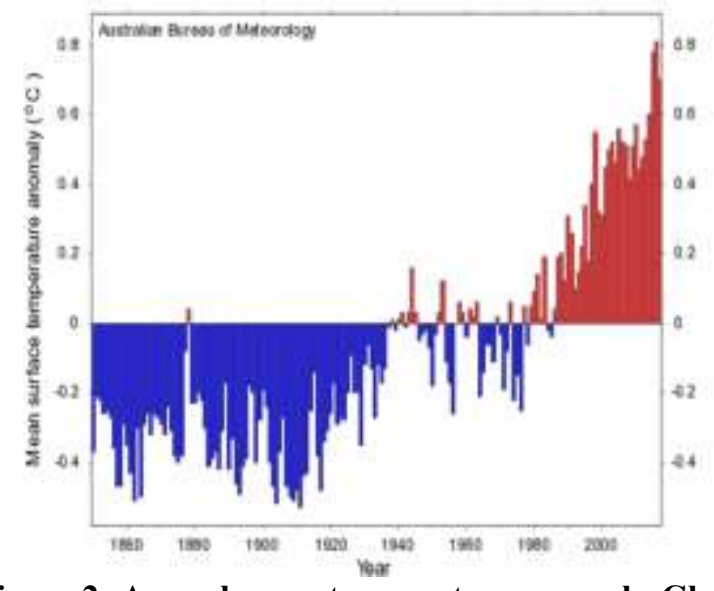

Figure 2: Annual mean temperature anomaly-Global (1850- 2017) (Source: Australian Bureau of Meteorology, 2018)

The global mean temperature is expected to increase in conjunction with the increase of $\mathrm{CO}_{2}$ concentration. There is a projection that the average of global temperature for the period 2081-2100 will exceed $2^{\circ} \mathrm{C}$ up to $1850-1900$ average. Therefore, the duration, frequency and magnitude of hot extreme globally are highly expected [9]. However, the current models may not able to simulate the trends of climate elements [10]. Also, global warming will be responsible for the spatial variation of the precipitation average over the earth surface. The contrast between dry and wet regions as well as wet and dry seasons in the average of annual mean precipitation is highly expected to increase as global temperatures increases. There are many areas around the world, such as arid and semi-arid as well as mid-latitude and subtropical areas will experience decreases in its precipitation [9]. There is evidence that climate change will cause the strongest impacts for several natural systems in many areas around the world [2]. Furthermore, climate change will affect all species in a different ecosystem [11].

\section{Study Area}

Samawah city is located in the south of Iraq at the intersection of latitude 31.7 north and longitude 44.85 east and it is the center of AlMuthanna province (Figure 3). The city surface height ranges from $8-10 \mathrm{~m}$ above sea level. It is located between the sedimentary plain and the western desert plateau. The river Euphrates passes through the center of Samawah, and the city has bordered from the north by Al- Diwaniya Governorate and from the east by the provinces of Basrah and Dhi Qar, whereas Al Najaf is located to the west [11].

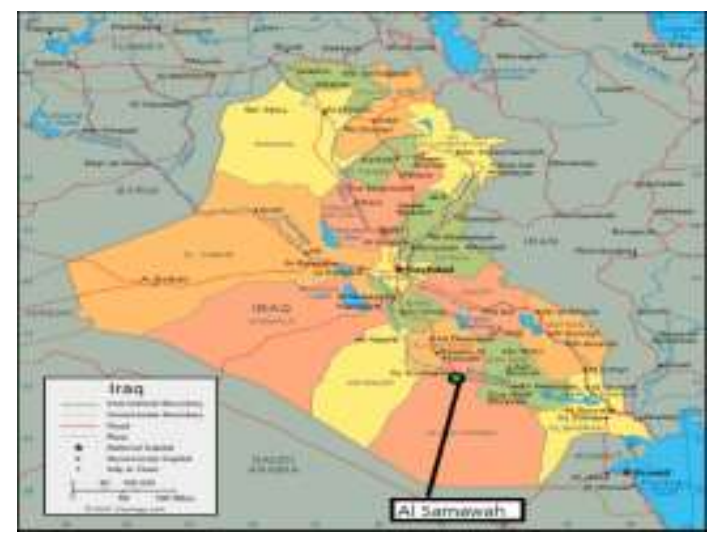

Figure 3: Location of the city of Samawah on the map of Iraq

\section{Methods}

To achieve the main objective of this research and that is the comparison of trends of mean temperature and rainfall rate in the city of Samawah with global climate change. Meteorological data from the different source were calculated and analyzed at multiple scales and for different timescales, such as monthly, seasonal and annual data for mean temperature and precipitation. In other words, global meteorological data and the observation data of meteorological station in samawah city have been analyzed to make a comparison between the change of climate elements that occurred at the local scale (Samawah city) and that occurred at the global scale. To get the annual mean temperature, monthly data of the average mean temperature which belong to Samawah meteorological station have been calculated. Also, the average of monthly data of mean 
temperature for the years from 2006 to 2015 has been calculated to compare the monthly and seasonal variation of the mean temperature in the city with global variation based on the average of mean temperature for the previous 30 years (1975-2005). Moreover, the averages of mean temperature for the previous ten years (19761985) which is considered the first ten years of previous thirty years (1975-2005) have been used.

\section{The Change of Climate Elements (Temperature and Rainfall) in Samawah City}

\section{I- The change of mean temperature}

Through the examining of mean temperature trend in the city of Samawah, it is clear that there is a marked change in its average and significantly above its overall average. By calculating the annual mean temperature from the data of meteorological station in the city, it's clear that there is a significant increase in annual averages of the current century, especially in recent years compared to the twentieth century, where the average of previous thirty years (19752005) was $24.5^{\circ} \mathrm{C}$. The average of mean temperature for the years from 1973 to 2007 was $24.6^{\circ} \mathrm{C}$ [12]. In more detail, when comparing annual mean temperature for the years from 2006 to 2015 with annual mean temperature of the years preceding it, we notice that there is a significant increase in annual mean temperature (Figure 4).

Also, if we compare the ten years of main annual temperature in the city of Samawah form 2005 to 2015 with the average of previous ten years (1975-2005), we find that there is an increase by $1.2^{\circ} \mathrm{C}$ (Table 1$)$.

\section{II-The change of maximum temperature}

The averages of maximum temperature in Samawah city for the ten years from 2006 to 2015 in generally experienced increases comparing to the previous thirty years average (1975-2005). Also, the average maximum temperature experienced fluctuation between the rise and declined slightly for some years. By comparing the annual average of maximum temperature for the period from 2005 to 2015 , there is an increase in the rates, especially in the last years of the data used to complete this research (Figure 5).

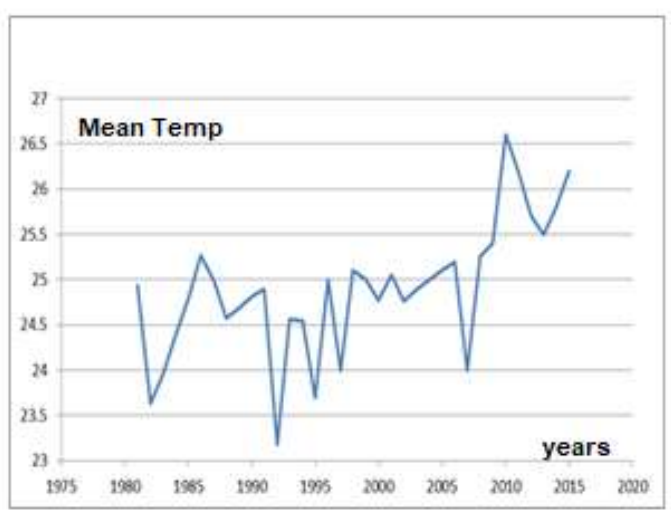

Figure 4: The change of main annual temperature in Samawah city since the twentieth century

Table 1: The change of annual mean temperature in Samawah city

\begin{tabular}{llll}
\hline \hline year & $\begin{array}{l}\text { Annual mean } \\
\text { Temp }{ }^{\circ} \mathrm{C}\end{array}$ & year & $\begin{array}{l}\text { Annual mean } \\
\text { Temp }{ }^{\circ} \mathrm{C}\end{array}$ \\
\hline 1976 & 23.62 & 2006 & 25.2 \\
1977 & 24.3 & 2007 & 24 \\
1978 & 24.3 & 2008 & 25.26 \\
1979 & 25.57 & 2009 & 25.4 \\
1980 & 24.39 & 2010 & 26.6 \\
1981 & 24.9 & 2011 & 26.2 \\
1982 & 23.61 & 2012 & 25.7 \\
1983 & 23.95 & 2013 & 25.5 \\
1984 & 24.38 & 2014 & 25.8 \\
1985 & 24.79 & 2015 & 26.2 \\
Average ${ }^{\circ} \mathrm{C}$ & 24.38 & & 25.58 \\
\hline
\end{tabular}

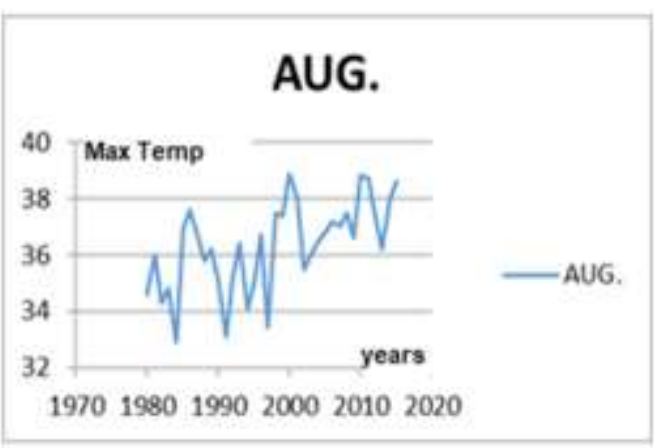

Figure 5: The change of the average maximum temperature for August in Samawah city since the twentieth century

\section{III-The change of annual average of rainfall}

The ten years of rainfall average $(100.86 \mathrm{~mm})$ from 2005 to 2015 is very close to the average of rainfall for the previous years (Table 2). The rainfall average for the period from 1973 to 2007 was $100.4 \mathrm{~mm}$ [12].

It is clear that the annual average of precipitation in Samawah city has fluctuated significantly due to the changes in climate, especially in the last 20 years (Figure 6) 
Table 2: The annual average of rainfall in Samawah city for the period (2006-2015)

\begin{tabular}{ll}
\hline \hline year & $\begin{array}{l}\text { Annual average of rainfall in Samawah city } \\
(\mathrm{mm})\end{array}$ \\
\hline 200 & 165.84 \\
6 & \\
200 & 62.28 \\
7 & \\
200 & 55.92 \\
8 & \\
200 & 54 \\
9 & \\
201 & 46.92 \\
0 & \\
201 & 58.32 \\
1 & \\
201 & 105.2 \\
2 & \\
201 & 247.9 \\
3 & \\
201 & 111.2 \\
4 & \\
201 & 101.1 \\
5 & \\
\hline
\end{tabular}

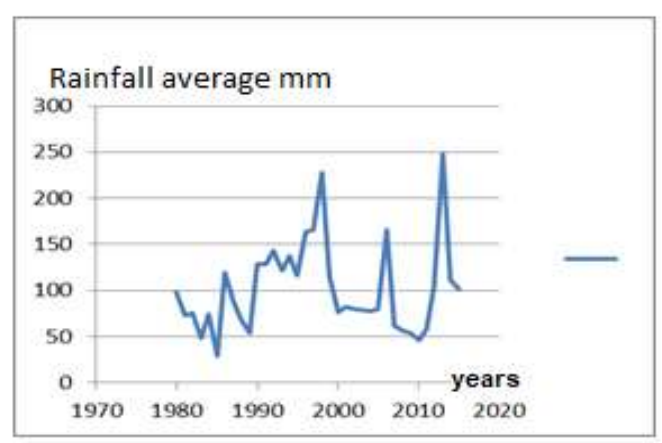

Figure 6: The annual average of rainfall in Samawah city since 1980

\section{Results and Discussions}

I. Comparing the change in annual mean temperature for Samawah city with its global change

Rising temperatures over the earth are a strong indicator of the anthropogenic causes of climate change [13]. However, there are various drivers can impact the observed temperature at multiple scales. Natural and anthropogenic drivers cause the variation of temperatures globally [5] and hence it is difficult to examine historical climate data at multiple scales to assess the causes of heat trends [13]. Also, the availability of meteorological data covers only the last 50 or 100 year. Moreover, both the surface of the earth and lower atmosphere are expected to be more warming [14]. Although many studies have tried to examine the differences of warming rate that observed between the earth surface and troposphere [15], there was little consideration of the differences between the global and local scale of climate change. This research included a comparison between the global climate change (global scale) and the changes of climate elements that happened in Samawah city (local scale). The results showed that there is a significant difference between the increasing annual mean temperature globally and the annual mean temperature in the city of Samawah. When comparing the increase in annual mean temperature of the city of Samawah for the period from 2006 to 2015 (ten years) based on the average of mean temperature for the previous 30 years (1975-2005) with the change of annual mean temperature globally [16], we note that there was increasing for the years 2010 and 2011 is almost four times and it was double for the years 2012, 2013, 2014 and 2015 higher than the increasing of annual mean temperature for the same years globally (Table 3 ).

\section{Comparing the change in annual mean temperature for Samawah city with its change in Northern Hemisphere}

The entire earth surface has experienced large warming since 20th century. However, many studies have shown that South Hemisphere warming is lower than in the North Hemisphere [7]. This research measures the correlation between the increase of annual mean temperature in the northern hemisphere [17] and the increase in the city of Samawah. The result showed that there is a large different between the increase in annual mean temperature in the Northern Hemisphere and the increase in annual mean temperature in the Samawah city and even in some years we find that the rate of increase in the city of Samawah is about three times the rate of increase in the northern half of the earth, such as in 2010 (Table 3).

III. Comparing the change of monthly and seasonal averages of mean temperature with their changes globally

The mean temperature of the hot months of the summer season (JJA), as well as spring months (MAM) in the city of Samawah, increased significantly compared to the rest of the months of the year and it is quite different from the change that occurred in the monthly mean temperature globally. From year to year, the greater variability of mean temperature in the Northern Hemisphere occurred in winter more than summer [4]. While the largest increase in the monthly average of mean temperature for ten 
years (2006-2015) occurred during the spring and summer months in the city of Samawah, the largest increase in the global average of monthly mean temperature occurred in the autumn and winter months (Table 4). changes in climate and contrast to the increase in its global average [18]. In the years in which the city of Samawah witnessed a decrease in the amount of rain falling, the amount of global rainfall has increased (Table 5).

\section{$I V$. Comparing the change of annual average of rainfall in Samawah city with its change globally}

The annual average of precipitation in Samawah city has fluctuated significantly due to the

Table 3: Comparing the change of annual mean temperature in Samawah city with its change Globally and in the NH for the period (2006-2015)

\begin{tabular}{|c|c|c|c|c|}
\hline year & $\begin{array}{l}\text { Annual mean } \\
\text { temperature }\left({ }^{\circ} \mathrm{C}\right)\end{array}$ & $\begin{array}{l}\text { Change in annual mean temperature (Samawah) } \\
\text { Compared to the average of the previous thirty years } \\
(1975-2005) / 24.51^{\circ} \mathrm{C}\end{array}$ & $\begin{array}{l}\text { Change in annual } \\
\text { mean temp }\left({ }^{\circ} \mathrm{C}\right) \\
(\text { Global) }\end{array}$ & $\begin{array}{l}\text { Change in annual } \\
\text { mean temp }\left({ }^{\circ} \mathrm{C}\right) \\
(\mathrm{NH})\end{array}$ \\
\hline $\begin{array}{l}200 \\
6\end{array}$ & 25.2 & 0.69 & 0.52 & 0.67 \\
\hline $\begin{array}{l}200 \\
7\end{array}$ & 24 & -0.51 & 0.51 & 0.71 \\
\hline $\begin{array}{l}200 \\
8\end{array}$ & 25.26 & 0.75 & 0.4 & 0.57 \\
\hline $\begin{array}{l}200 \\
9\end{array}$ & 25.4 & 0.89 & 0.51 & 0.60 \\
\hline $\begin{array}{l}201 \\
0\end{array}$ & 26.6 & 2.09 & 0.57 & 0.74 \\
\hline $\begin{array}{l}201 \\
1\end{array}$ & 26.2 & 1.69 & 0.43 & 0.57 \\
\hline $\begin{array}{l}201 \\
2\end{array}$ & 25.7 & 1.19 & 0.48 & 0.63 \\
\hline $\begin{array}{l}201 \\
3\end{array}$ & 25.5 & 0.99 & 0.53 & 0.67 \\
\hline $\begin{array}{l}201 \\
4\end{array}$ & 25.8 & 1.29 & 0.6 & 0.77 \\
\hline $\begin{array}{l}201 \\
5\end{array}$ & 26.2 & 1.69 & 0.78 & 1.03 \\
\hline
\end{tabular}

Table 4: Comparing the change of monthly mean temperature in Samawah city with its change globally

\begin{tabular}{lllll}
\hline \hline Month & $\begin{array}{l}\text { Monthly average of mean } \\
\text { temp for 10years }(1976-1985) \\
\left({ }^{\circ} \mathrm{C}\right)\end{array}$ & $\begin{array}{l}\text { Monthly average of mean } \\
\text { temp for 10years }(2006- \\
2015)\left({ }^{\circ} \mathrm{C}\right)\end{array}$ & $\begin{array}{l}\text { The rate of } \\
\text { change }\left({ }^{\circ} \mathrm{C}\right)\end{array}$ & $\begin{array}{l}\text { Change in monthly } \\
\text { average globally for years } \\
(2006-2015)\end{array}$ \\
\hline Jan & 11.28 & 11.71 & 0.43 & 0.83 \\
\hline Feb & 13.76 & 14.64 & 0.88 & 0.78 \\
\hline Mar & 18.18 & 20.23 & 2.05 & 0.85 \\
\hline Apr & 24.78 & 25.56 & 0.78 & 0.79 \\
\hline May & 30.26 & 32.28 & 2.02 & 0.79 \\
\hline Jun & 34.17 & 36.11 & 1.94 & 0.75 \\
\hline Jul & 35.87 & 37.31 & 1.44 & 0.72 \\
\hline Aug & 34.73 & 37.6 & 2.87 & 0.8 \\
\hline Sep & 32.9 & 33.39 & 0.49 & 0.89 \\
\hline Oct & 25.8 & 27.55 & 1.75 & 0.87 \\
\hline Nov & 18.1 & 18.57 & 0.47 & 0.84 \\
\hline Dec & 12.76 & 13.36 & 0.6 & 0.84 \\
\hline
\end{tabular}

Table 5: comparing the change in annual average rainfall in Samawah city with its global change

\begin{tabular}{llll}
\hline \hline year & $\begin{array}{l}\text { The annual average of rainfall in } \\
\text { Samawah city }(\mathrm{mm})\end{array}$ & $\begin{array}{l}\text { The change in annual average } \\
\text { rainfall in Samawah city }(\mathrm{mm})\end{array}$ & $\begin{array}{l}\text { The change in annual average } \\
\text { rainfall globally }(\mathrm{mm})\end{array}$ \\
\hline 2006 & 165.84 & 65.4 & 33.67 \\
2007 & 62.28 & -38.16 & 7.13 \\
2008 & 55.92 & -44.54 & 29.69 \\
2009 & 54 & -46.44 & -8.10 \\
2010 & 46.92 & -53.52 & 51.17 \\
2011 & 58.32 & -42.12 & 46.24 \\
2012 & 105.2 & 4.76 & 0.49 \\
2013 & 247.9 & 147.46 & -0.13 \\
2014 & 111.2 & 10.76 & -3.35 \\
\hline
\end{tabular}




\section{$V$. The impacts of climate change in the city of Samawah}

Climate change continues to affect the quantity and distribution of rain in many parts of the world and this, in turn, causes many of the phenomena that can damage the ecosystems, the most prominent of these phenomena are long droughts and fluctuation in rainfall, which in turn leads to desertification, land erosion and dust storms . Especially when drought and rainfall are associated with high temperatures. For example, comparing the number of dust storms in the city of Samawah for the period from 1980 to 1985 with its number for the period from 2010 to 2015 indicates that there is a marked increase in its frequency (Table 6).

Table 6: The number of dust storms in Samawah city

\begin{tabular}{ccccccccccccc}
\hline \hline Dec & Nov & Oct & Sep & Aug & Jul & Jun & May & Apr & Mar & Feb & Jan & Month \\
\hline 0 & 0 & 0 & 0 & 0 & 0 & 0 & 0 & 0 & 0 & 0 & 0 & 1980 \\
0 & 0 & 0 & 0 & 0 & 0 & 0 & 2 & 2 & 0 & 0 & 0 & 1981 \\
0 & 0 & 0 & 0 & 0 & 0 & 0 & 1 & 0 & 1 & 0 & 0 & 1982 \\
0 & 0 & 0 & 0 & 0 & 0 & 0 & 1 & 0 & 0 & 0 & 0 & 1983 \\
0 & 0 & 1 & 0 & 0 & 0 & 0 & 0 & 2 & 0 & 0 & 0 & 1984 \\
0 & 0 & 0 & 0 & 0 & 0 & 0 & 0 & 0 & 0 & 0 & 0 & 1985 \\
0 & 0 & 1 & 2 & 0 & 3 & 2 & 1 & 1 & 1 & 0 & 0 & 2010 \\
0 & 0 & 0 & 0 & 0 & 1 & 2 & 2 & 1 & 1 & 0 & 0 & 2011 \\
0 & 0 & 0 & 0 & 0 & 0 & 0 & 5 & 4 & 4 & 2 & 0 & 2012 \\
0 & 0 & 0 & 0 & 0 & 0 & 1 & 0 & 2 & 1 & 0 & 0 & 2013 \\
0 & 0 & 0 & 0 & 0 & 0 & 0 & 1 & 0 & 0 & 0 & 0 & 2014 \\
0 & 0 & 0 & 0 & 0 & 0 & 0 & 3 & 1 & 1 & 0 & 0 & 2015 \\
\hline
\end{tabular}

\section{4- Conclusion}

Climate change has taken place across the world as a result of the increase in the concentrations of greenhouse gases which in turn represent the main cause for global warming. Much research has not addressed the differences in the magnitude of climate change at the local and global scales. This study examines the differences in climate changes between the local and global scales, and this is by comparing the changes in climate elements in the city of Samawah and its global counterpart. The results showed that there are significant differences between the changes in annual mean temperature and rainfall rates in the city of Samawah and its counterpart globally. For example, the increase in annual mean temperature in the city of Samawah exceeded the increase in global mean temperature by almost four times for the years 2010 and 2011. Also, the result showed that the increase in the average monthly mean temperature in the city of Samawah is quite different from the increase in the global level. While the city of Samawah recorded the highest increases of monthly mean temperature in hot months of the year, the highest increases of monthly mean temperature happened over the world in relatively cold months. As for the change in rainfall, in the years in which the city of Samawah witnessed a decrease in the amount of rain falling, the amount of rainfall has increased at the global scale. All these dramatic changes in the climate of the city of Samawah will certainly lead to several phenomena, such as the desertification, land erosion and dust storms.

\section{References}

[1] M. Hertzberg, and H. Schreuder, "Role of atmospheric carbon dioxide in climate change," Energy and Environment, Vol. 27, No. 6, pp. 785-797, 2016.

[2] IPCC, Climate Change: Synthesis Report. Contribution of Working Groups I, II and III to the Fifth Assessment Report of the Intergovernmental Panel on Climate Change [Core Writing Team, R.K. Pachauri and L.A. Meyer (eds.)].IPCC, Geneva, Switzerland, pp 151, 2014.

[3] D. Benjamin, H. Hui for, and D. Budescu, "Climate change versus Global Warming: Who is Susceptible to the Framing of Climate Change? ", Environment and Behavior, Vol. 49, No. 7, pp. 745-770, 2017.

[4] P. D.Jones, New, M., Parker, D.E., Martin, S. and Rigor, I.G, "Surface air temperature and its variations over the last 150 years". Reviews of Geophysics, vol. 37, No. 2, pp. 173-199, 1999.

[5] P. J. Lloyd, "An Estimate of the Centennial Variability of Global Temperatures," Energy and Environment Vol. 26, No. 3, pp. 417-424, 2015.

[6] P.D. Jones, D.H. Lister, T.J. Osborn, C. Harpham, M. Salmon, and C.P. Morice, "Hemispheric and large-scale land surface air temperature variations: an extensive revision and an update to 2010", Journal of Geophysical 424, 2012.

[7] Y. Xu, and V. Ramanathan, "Latitudinally asymmetric response of global surface temperature: Implication for regional climate change," GeophysicalResearch Letters, Vol. 39, No. 10, pp. 706-711, 2012. 
[8] M. Ogurtsov, and M. Lindholm, "Uncertainties in Assessing Global Warming during the 20th Century: Disagreement Between Key Data Sources", Energy and Environment, Vol. 17, No. 5, pp. 685-706, 2006.

[9] M. Collins, R. Knutti, J. Arblaster, J. Dufresne, T. Fichefet, P. Friedlingstein, X. Gao, W.J. Gutowski, T. Johns, G. Krinner, M. Shongwe, C. Tebaldi, A.J. Weaver and M. Wehner, Long-term Climate Change: Projections, Commitments and Irreversibility. In: Climate Change 2013: The Physical Science Basis, Contribution of Working Group I to the Fifth Assessment Report of the Intergovernmental Panel on Climate Change [Stocker, T.F., D. Qin, G.-K. Plattner, M. Tignor, S.K. Allen, J. Boschung, A. Nauels, Y. Xia, V. Bex and P.M. Midgley (eds.)]. Cambridge University Press, Cambridge, United Kingdom and New York, NY, USA, 2013.

[10] Ya. K. Kondrayev, "Key Aspects of Global Climate Chang," Energy and Environment, Vol. 15, No. 3, pp. 469503, 2004.

[11] K .J Feeley, J. T. Stroud, and T.M. Perez, "Most global reviews of species responses to climate change are not truly global," Diversity and Distributions, Vol. 23, No. 10, pp. 231-234, 2017.

[12] W. K. Sabri, "Dune in Muthanna Governorate, Applied Geomorphic Study," M.Sc. Thesis, Geography Dept., Univ. of Baghdad, Iraq, 2010.

[13] C. Loehle, Trend Analysis of Satellite Global Temperature Data, Energy and Environment, Vol. 20, No. 7, pp. 1087-1098, 2009.

[14] A. Rosema, S. foppes and J. Van der, Meteosat Deriver Planetary Temperature Trend 1982-2006, Energy and Environment, Vol. 24, No. 3, pp. 381-395, 2013.

[15] D.H. Douglass and J.R. Christy, Reconciling Observations of Global Temperature Change: 2013, Energy and Environment, Vol. 24, No. 3, pp. 415-419, 2013.

[16] Australian bureau of Meteorology, Available: http://www.bom.gov.au/web01/ncc/www/cli_chg/timeseri es/global_t/0112/global/latest.txt.

[17] GISTEMP Team: GISS Surface Temperature Analysis (GISTEMP). NASA Goddard Institute for Space Studies, 2018. Dataset accessed 20YY-MM-DD at https://ata.giss.nasa.gov/gistemp/.

[18] Australian bureau of Meteorology, Available: http://www.bom.gov.au/web01/ncc/www/cli_chg/timeseri es/global_r/0112/global/latest.txt. 